\title{
Regulation of Aquaporin Functional Properties Mediated by the Antioxidant Effects of Natural Compounds
}

\author{
Giorgia Pellavio ${ }^{1}$, Marta Rui ${ }^{2}$, Laura Caliogna ${ }^{3}$, Emanuela Martino ${ }^{4}$, Giulia Gastaldi ${ }^{1}$ (D), \\ Simona Collina ${ }^{2}$ (D) and Umberto Laforenza ${ }^{1, *}$ (D) \\ 1 Department of Molecular Medicine, Human Physiology Unit, University of Pavia, I-27100 Pavia, Italy; \\ giorgia.pellavio@gmail.com (G.P.); gastaldi@unipv.it (G.G.) \\ 2 Department of Drug Sciences, Medicinal Chemistry and Pharmaceutical Technology Section, \\ University of Pavia, I-27100 Pavia, Italy; marta.rui01@universitadipavia.it (M.R.); \\ simona.collina@unipv.it (S.C.) \\ 3 Operative Unit of Orthopaedics and Traumatology, Fondazione IRCCS Policlinico San Matteo, \\ I-27100 Pavia, Italy; L.Caliogna@smatteo.pv.it \\ 4 Department of Earth and Environmental Sciences, University of Pavia, I-27100 Pavia, Italy; \\ emanuela.martino@unipv.it \\ * Correspondence: lumberto@unipv.it; Tel.: +39-0382-98-7568
}

Received: 15 November 2017; Accepted: 6 December 2017; Published: 8 December 2017

\begin{abstract}
Some aquaporins (AQPs) have been recently demonstrated to facilitate the diffusion of hydrogen peroxide $\left(\mathrm{H}_{2} \mathrm{O}_{2}\right)$ from the producing cells to the extracellular fluid, and their reactive oxygen species scavenging properties have been defined. Nevertheless, the identification of different AQPs acting as peroxiporins, their functional role in eustress and distress, and the identification of antioxidant compounds able to regulate AQP gating, remain unsolved. This study aims to investigate, in HeLa cells: (1) the expression of different AQPs; (2) the evaluation of naringenin, quercetin, $(R)$-aloesaponol III 8-methyl ether, marrubiin, and curcumin antioxidant profiles, via $\alpha, \alpha$-diphenyl- $\beta$-picrylhydrazyl assay; (3) the effect of the compounds on the water permeability in the presence and in the absence of oxidative stress; and (4) the effect of pre- and post-treatment with the compounds on the $\mathrm{H}_{2} \mathrm{O}_{2}$ content in heat-stressed cells. Results showed that HeLa cells expressed AQP1, 3, 8, and 11 proteins. The oxidative stress reduced the water transport, and both pre- and post-treatment with the natural compounds recovering the water permeability, with the exception of curcumin. Moreover, the pre- and post-treatment with all the compounds reduced the $\mathrm{H}_{2} \mathrm{O}_{2}$ content of heat-stressed cells. This study confirms that oxidative stress reduced water AQP-mediated permeability, reversed by some chemical antioxidant compounds. Moreover, curcumin was shown to regulate AQP gating. This suggests a novel mechanism to regulate cell signaling and survival during stress, and to manipulate key signaling pathways in cancer and degenerative diseases.
\end{abstract}

Keywords: water channel; oxidative stress; antioxidant compounds; hydrogen peroxide

\section{Introduction}

Hydrogen peroxide $\left(\mathrm{H}_{2} \mathrm{O}_{2}\right)$ is one of the most abundant and stable reactive oxygen species (ROS) in organisms, produced by superoxide dismutase (SOD) from the superoxide anion, ${ }^{\bullet} \mathrm{O}_{2}{ }^{-}[1-3]$. Cells can generate $\mathrm{H}_{2} \mathrm{O}_{2}$ by NADPH oxidases (NOX) in the plasma membrane, by oxidative phosphorylation in mitochondria, and by oxidative protein folding in the endoplasmic reticulum [4]. ROS like $\mathrm{H}_{2} \mathrm{O}_{2}$ and 4-hydroxynonenal can exert a physiological effect at low concentrations, acting as 
intracellular second messengers (signaling molecules), or a cytotoxic effect at high concentrations that may trigger programmed cell death (apoptosis). Thus, the oxidative stress results from the imbalance occurring in the cells between ROS production and scavenging systems or detoxification. Great interest was aroused by the discovery that some aquaporins (AQPs) can facilitate the diffusion of $\mathrm{H}_{2} \mathrm{O}_{2}$ from the producing cells across the plasma membranes to the extracellular fluid $[5,6]$. The transport of $\mathrm{H}_{2} \mathrm{O}_{2}$ across membranes by specific AQPs has been considered the last milestone in the timeline of hydrogen peroxide discoveries in chemistry and biology $[7,8]$.

AQPs are a family of water channel proteins present in mammals in thirteen isoforms (named from AQP0 to AQP12) with different permeability features and different localizations at cellular and subcellular levels [9-11]. To date, AQP3, AQP5, AQP8, AQP9 were found to facilitate $\mathrm{H}_{2} \mathrm{O}_{2}$ diffusion [6,12-19], even though experimental evidence suggests that all water-permeable AQPs can act as peroxiporins, but with different $\mathrm{H}_{2} \mathrm{O}_{2}$ permeabilities: aquaammoniaporins > orthodox aquaporins $>$ aquaglyceroporins [20]. Furthermore, AQP11, an AQP localized in the endoplasmic reticulum, shows a major role in preventing glucose-induced oxidative stress in kidney proximal tubules, but so far, it has not been directly demonstrated to play a role in $\mathrm{H}_{2} \mathrm{O}_{2}$ diffusion [21].

Physiological role for AQP-mediated transmembrane diffusion of hydrogen peroxide in mammalian cells was demonstrated for some AQPs. The direct experimental evidence for AQP-mediated facilitated transmembrane diffusion of $\mathrm{H}_{2} \mathrm{O}_{2}$ across the yeast plasma membrane was obtained by using ROS-sensitive fluorescent dye [12]. The results obtained show that addition of $\mathrm{H}_{2} \mathrm{O}_{2}$ to yeast cells expressing human AQP8 and plant AtTIP1;1, AtTIP1;2, but not hAQP1, significantly increased the intracellular fluorescence. Successively, AQP3 was also demonstrated to mediate hydrogen peroxide uptake and to regulate downstream intracellular signaling [15]. The role of AQP3 in the transmembrane transmission of $\mathrm{H}_{2} \mathrm{O}_{2}$ signals was confirmed by Hara-Chikuma et al. [16]. In detail, the authors demonstrated that AQP3-mediated $\mathrm{H}_{2} \mathrm{O}_{2}$ transport is required for chemokine-dependent $\mathrm{T}$ cell migration during the immune response in mice. The involvement of AQP3 in $\mathrm{H}_{2} \mathrm{O}_{2}$ entry and the related cell signaling in cancer cells suggest that AQP3 may represent a new potential therapeutic target for cancer treatment [22,23]. More recently, $\mathrm{H}_{2} \mathrm{O}_{2}$ entry through AQP3 was found to be crucial for wound healing and innate immune function [18].

The expression of rat AQP5 in the Saccharomyces cerevisiae model has shown that it also has the property to transport $\mathrm{H}_{2} \mathrm{O}_{2}$, thus modulating the cell response to oxidative stress status [19].

After Miller's study, AQP8 involvement in $\mathrm{H}_{2} \mathrm{O}_{2}$ transport was also confirmed by Sitia's group using HeLa cells expressing the fluorescent $\mathrm{H}_{2} \mathrm{O}_{2}$ sensor HyPer [24]. Moreover, they found that AQP8 silencing inhibited not only the $\mathrm{H}_{2} \mathrm{O}_{2}$ entry, but also the phosphorylation of downstream proteins induced by EGF. Further studies showed that different cellular stress conditions reversibly inhibit the permeability of AQP8 to both $\mathrm{H}_{2} \mathrm{O}_{2}$ and water. Neither $\mathrm{H}_{2} \mathrm{O}_{2}$ nor water uptake is impaired in stressed cells expressing a mutant C53S AQP8. Cells expressing this mutant do not accumulate intracellular ROS, and are more resistant to stress-induced growth arrest and death [14].

The involvement of AQP9 in $\mathrm{H}_{2} \mathrm{O}_{2}$ transport was also clearly demonstrated by using Chinese hamster ovary (CHO)-K1 cells with an enforced expression of human AQP9, human AQP9 knockdown HepG2 cells and cells from AQP9 null mice [17]. Recently, we demonstrated the aquaporin-mediated water and $\mathrm{H}_{2} \mathrm{O}_{2}$ transport involvement in normal human spermatozoa functioning [25]. Sperm cells show water and $\mathrm{H}_{2} \mathrm{O}_{2}$ permeability, which was reversibly inhibited by heat stress and the AQP inhibitor $\mathrm{HgCl}_{2}$. Reduced functionality is observed in patients with compromised basal semen parameters, suggesting that AQPs are involved in both volume regulation and ROS elimination.

To sum up, it is clear that AQPs may have a beneficial effect in oxidative stress through a ROS scavenging mechanism, even if some AQP aspects remain unsolved, such as the identification and localization of different AQPs acting as peroxiporins, and their functional role in eustress and distress. In this scenario, the identification of antioxidant compounds able to regulate AQP gating could have a relevant role in understanding the AQP function mechanism. The last issue is the most intriguing, considering that so far, few potential AQP modulators have been identified to date, and their activity 
sometimes questioned. However, experimental evidence supports AQPs as possible "druggable" proteins $[26,27]$.

Therefore, the study herein presented is aimed (1) to select some natural structurally unrelated compounds, endowed with free radical scavenging (FRS) activities ( $\alpha, \alpha$-diphenyl- $\beta$-picrylhydrazyl, $\mathrm{DPPH}$, assay), useful for studying AQPs; (2) to evaluate the expression of mRNA and proteins of different AQPs in HeLa cells by RT-PCR and immunoblotting; (3) to evaluate the water permeability using stopped-flow light scattering method, and the gating of AQPs in presence and in the absence of oxidative stress; and (4) to evaluate the $\mathrm{H}_{2} \mathrm{O}_{2}$ levels in heat-stressed HeLa cells in the presence of the selected antioxidant compounds, measured by a fluorescence method.

\section{Results}

\subsection{Compound Selection and Free Radical Scavenging (FRS) Activity}

The final aim of this work is to identify compounds able to interact with AQP, and to understand, if possible, their action mechanisms. On the basis of our previous experience, we consider five not-structurally related [28,29] natural compounds, belonging to different chemical classes, i.e., quercetin (QUER), naringenin (NRG), (R)-aloesaponol III 8-methyl ether (ASME), curcumin (CURC), marrubiin (MARR), (Table 1, Figure 1).

Table 1. Biological activity, natural sources, and chemical class of the compounds tested.

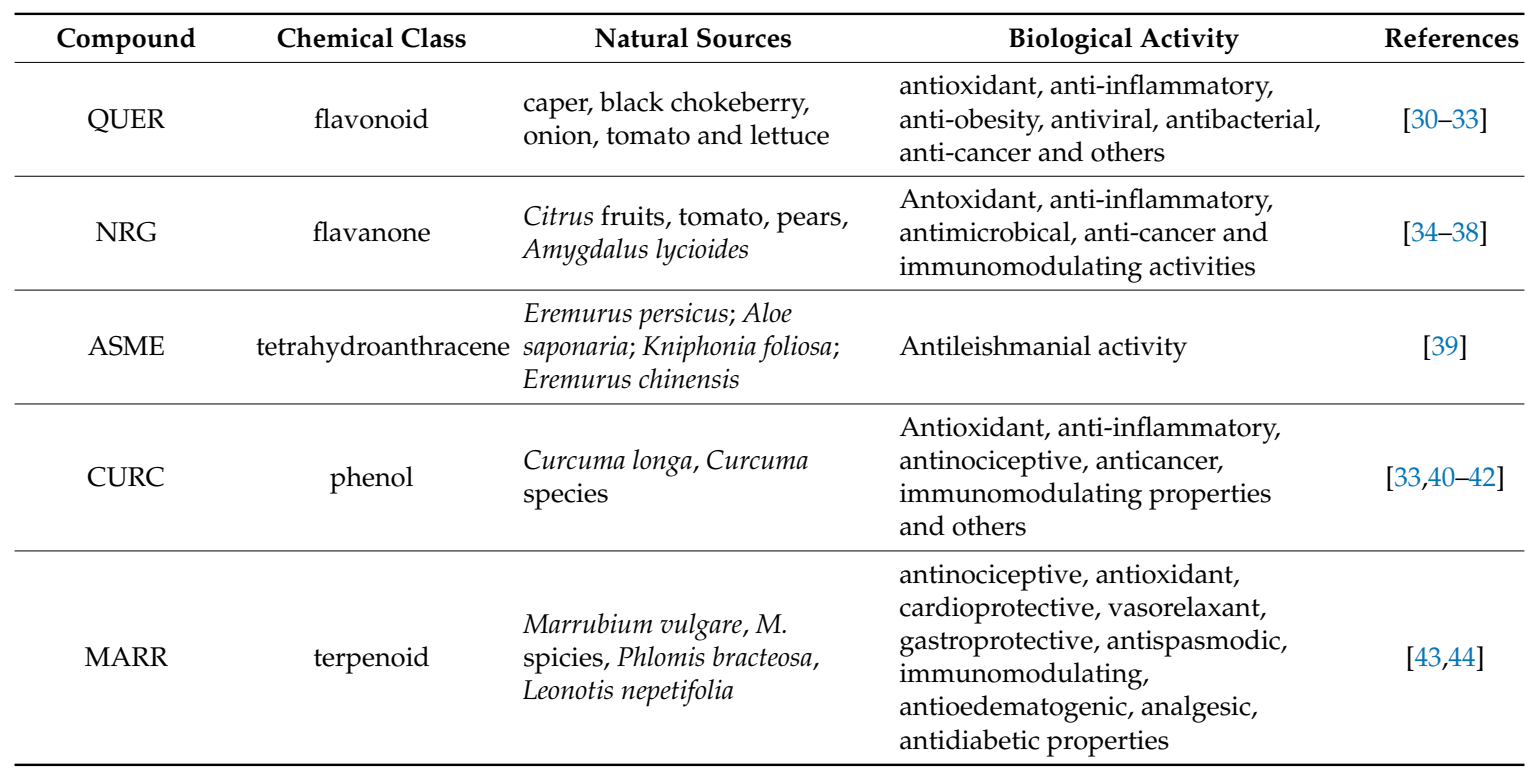

Abbreviations: QUER, quercetin; NRG, naringenin; ASME, (R)-aloesaponol III 8-methyl ether; CURC, curcumin; MARR, marrubiin.

As a first screening, we performed the DPPH assay, commonly used to determine FRS activity of natural compounds [45]. Moreover, this assay can be helpful in lead-finding of novel antioxidants. DPPH gives rise to a stable radical able to remove a hydrogen atom from the antioxidant (ArOH) that itself becomes a radical, leading to a decrease in the absorbance value $(\lambda=517 \mathrm{~nm})$ :

$$
\mathrm{R}+\mathrm{ArOH} \rightarrow \mathrm{RH}+\mathrm{ArO}
$$

In this work, we evaluate the FRS properties of compounds reported in Figure 1, using QUER as positive control $\left(\mathrm{IC}_{50}=2.1 \pm 0.1\right)$ [46]. In details, stock solutions of NRG, QUER, ASME, CURC and MARR in methanol were prepared into a range of $1.25-20 \mu \mathrm{g} / \mathrm{mL}$ or $1.25-40 \mu \mathrm{g} / \mathrm{mL}$, depending on compound solubility, added to a methanolic solution of DPPH, and the absorbance of the resulting solutions evaluated. Results showed a non-linear regression feature of the experimental points 
(Figure 2A). The maximal FRS activity, Ymax, was obtained by fitting the data with the one phase exponential association (see Materials and Methods) and showed in Figure 2B. Ymax was significantly higher for QUER compared to other compounds tested. The FRS activity order was the following: QUER $>>$ CURC $>N R G \cong$ ASME $>$ MARR (Figure 2B).<smiles>O=c1c(O)c(-c2ccc(O)c(O)c2)oc2cc(O)cc(O)c12</smiles>
(QUER)<smiles>O=C1CC(c2ccc(O)cc2)Oc2cc(O)cc(O)c21</smiles>

Naringenin (NRG)<smiles>COc1cc(C)cc2cc3c(c(O)c12)C(=O)CC[C@H]3O</smiles>

$(R)$-aloesaponol III 8-methyl ether (ASME)<smiles>COc1cc(/C=C/C(=O)CC(=O)/C=C/c2ccc(O)c(OC)c2)ccc1O</smiles>

Curcumin (CURC)

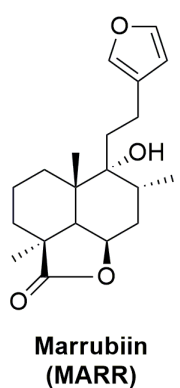

Figure 1. Chemical structures of quercetin (QUER), naringenin (NRG), (R)-aloesaponol III 8-methyl ether (ASME), curcumin (CURC), marrubiin (MARR).

A

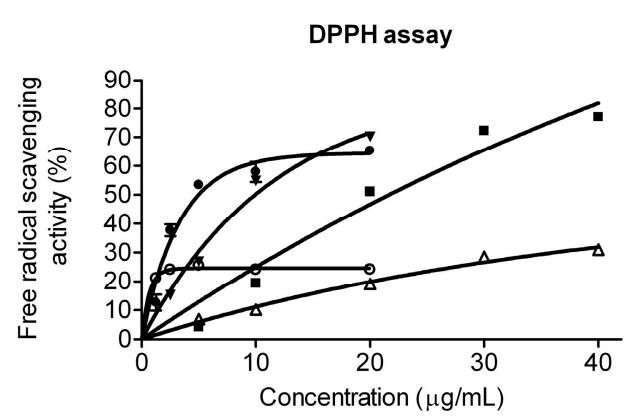

B

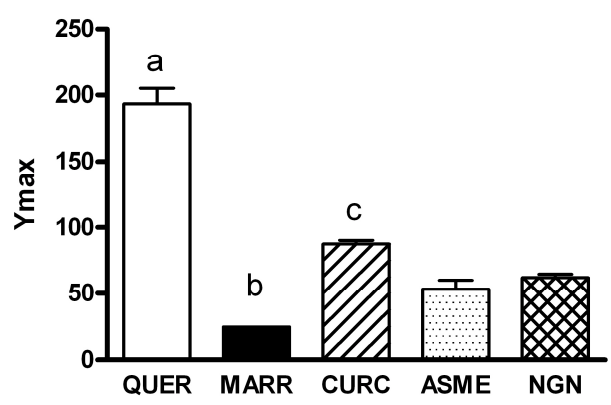

Figure 2. Antioxidant activity determination of quercetin (QUER), marrubiin (MARR), curcumin (CURC), ASME, and naringenin (NRG) by a $\alpha$, $\alpha$-diphenyl- $\beta$-picrylhydrazyl (DPPH). DPPH assay was performed as described in Materials and Methods. (A) Free radical scavenging activity of the compounds was determined as a function of increasing compound concentration. The curves were obtained by fitting the experimental points with computerized least-square regression (see Materials and Methods). The symbols represent means \pm SEM of three different experiments. When not shown, SEM were within the symbol area; (B) Bars represent the Ymax constant values, obtained as described above. Values are means \pm SEM of 3-6 different experiments. (a) $p<0.05$ vs. MARR, CURC, ASME, NRG; (b) $p<0.05$ vs. CURC, ASME, NRG; (c) $p<0.05$ vs. ASME, NRG (ANOVA followed by Newman-Keuls' $Q$ test).

\subsection{AQP1, 3, 8, 9, and $11 \mathrm{mRNA}$ Are Expressed in HeLa Cells}

First, we explored by RT-PCR the expression of AQP1-11 mRNA in HeLa cells. AQP1, 3, 8, 9, and 11 transcripts were expressed (Figure 3A). Gel electrophoresis showed single bands of the expected size of the amplified cDNA fragments: $229 \mathrm{bp}$ for AQP1, $414 \mathrm{bp}$ for AQP3, $282 \mathrm{bp}$ for AQP8, $432 \mathrm{bp}$ for $\mathrm{AQP9}$, and $141 \mathrm{bp}$ for AQP11. Similar results were obtained from at least three different RNA extracts. 
A $\begin{array}{lllllllllllll}M W & 1 & 2 & 3 & 4 & 5 & 6 & 7 & 8 & 9 & 10 & 11 & \mathrm{~B}\end{array}$

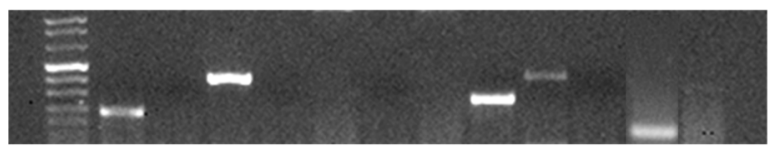

B

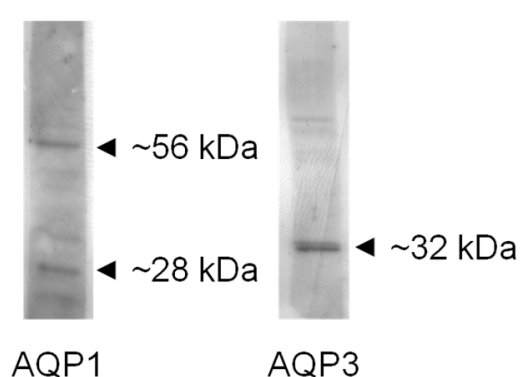

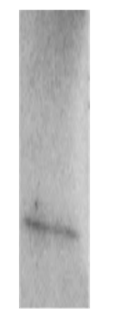

AQP8 AQP8

(sc-81870) (4ADI)
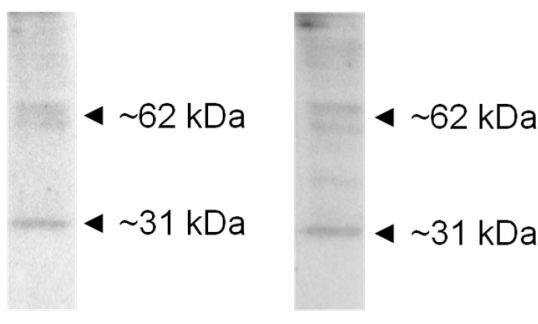

AQP11

Figure 3. Aquaporin (AQP) mRNA (A) and protein (B) expression in HeLa cells. (A) RT-PCR of total RNA was performed by using specific primers listed in Table 1. Gel electrophoresis showed specific PCR products for AQP1 (229 bp band), AQP3 (414 bp band), AQP8 (282 bp band), AQP9 (432 bp band), and AQP11 (141 bp). Similar results were obtained from at least three different RNA extracts. MW, molecular weight marker. B, negative control; (B) Blots representative of three were shown. Lanes were loaded with $30 \mu \mathrm{g}$ of proteins, probed with affinity purified antibodies, and processed as described in Materials and Methods. Major bands of about $28 \mathrm{kDa}$ (monomer) and $56 \mathrm{kDa}$ (dimer) were observed for AQP1. A single band of about $32 \mathrm{kDa}$ was observed for AQP3 and 8 (using sc-81870 antibody). Major bands of about $31 \mathrm{kDa}$ (monomer) and $62 \mathrm{kDa}$ (dimer) were observed for AQP8 (using 4ADI antibody) and AQP11.

\subsection{AQP1, 3, 8, and 11, but Not AQP9, Protein Are Expressed in HeLa Cells}

The expression of AQP proteins in HeLa cells was studied by immunoblotting using affinity pure antibodies. The results indicated that AQP1, 3, 8, and 11 were expressed, while AQP9 protein was not found (Figure 3B). Immunoblots showed major bands of about $28 \mathrm{kDa}$ (monomer) and $56 \mathrm{kDa}$ (dimer) for AQP1. A single band of about $32 \mathrm{kDa}$ was observed for AQP3 and 8 (using Santa Cruz sc- 81870 antibody). Major bands of about $31 \mathrm{kDa}$ (monomer) and $62 \mathrm{kDa}$ (dimer) were observed for AQP8 (using Alpha Diagnostic antibody) and AQP11. Similar results were obtained from at least three different experiments. No specific bands were observed when the blots were probed with anti-AQP9. The specificity of the reactions was previously characterized, and checked in experiments performed by incubating the blots with pre-immune rabbit serum .as stated in Materials and Methods.

\subsection{Effect of Antioxidant Compounds on the Water Permeability in the Presence and in the Absence of Oxidative Stress}

HeLa cells' exposure to a hypotonic environment caused rapid swelling. The resulting decrease in scattered light intensity was analyzed by a one phase exponential decay equation, and the initial rate constants $k$ obtained (Figure 4). Then, to study the effect of oxidative stress on osmotic water permeability, we decided to use heat shock as well-known cell stressor [47]. Heat-treated cells exhibited a significant decrease in water transport when exposed to a hypotonic gradient (Figures 4 and 5). The presence of QUER, MARR, ASME, or NRG during heat treatment prevented the water permeability decrease (Figures $4 \mathrm{~B}$ and 5). After heat treatment, the incubation of the cells for $30 \mathrm{~min}$ with the same compounds restored the water permeability (Figure 5). On the contrary, CURC did not protect nor restore the water permeability of heat-treated cells. 
Water permeability experiments were also performed in HeLa cells incubated at room temperature (in the absence of oxidative stress) in the presence of QUER, MARR, CURC, ASME, and NRG. Unexpectedly, CURC significantly inhibited the water permeability, while other compounds were ineffective (Figure 5, CONTROLS).

A

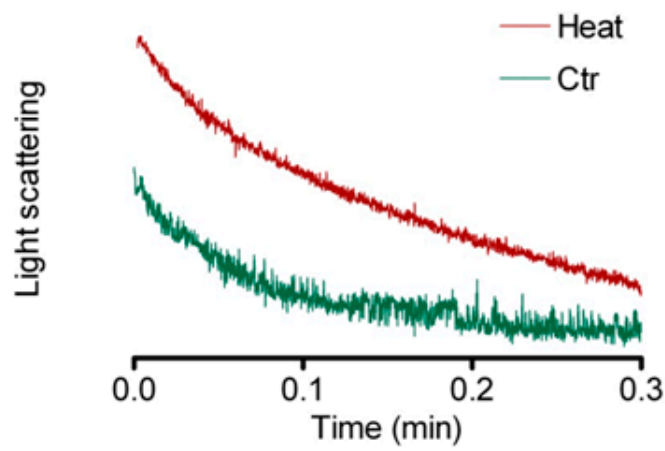

B

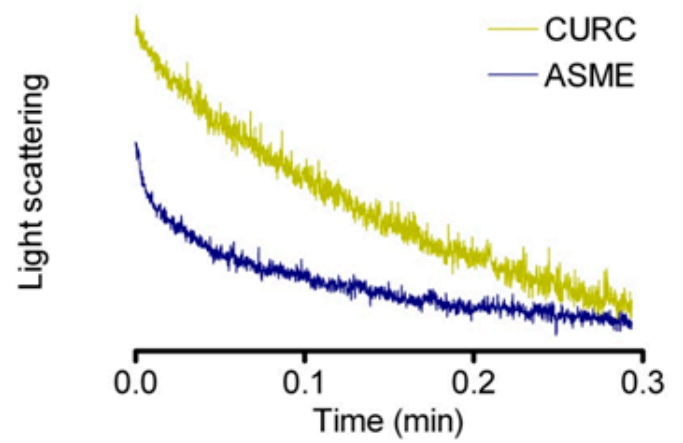

Figure 4. Representative traces of stopped-flow osmotic water permeability measurements obtained from HeLa cells. (A) Normal (Ctr) and heat-stress (Heat) conditions; (B) effect of pre-treatment with curcumin (CURC) and ASME in heat-stress conditions. HeLa cells were treated as reported in Materials and Methods, and then exposed to a 150 mOsm osmotic gradient.
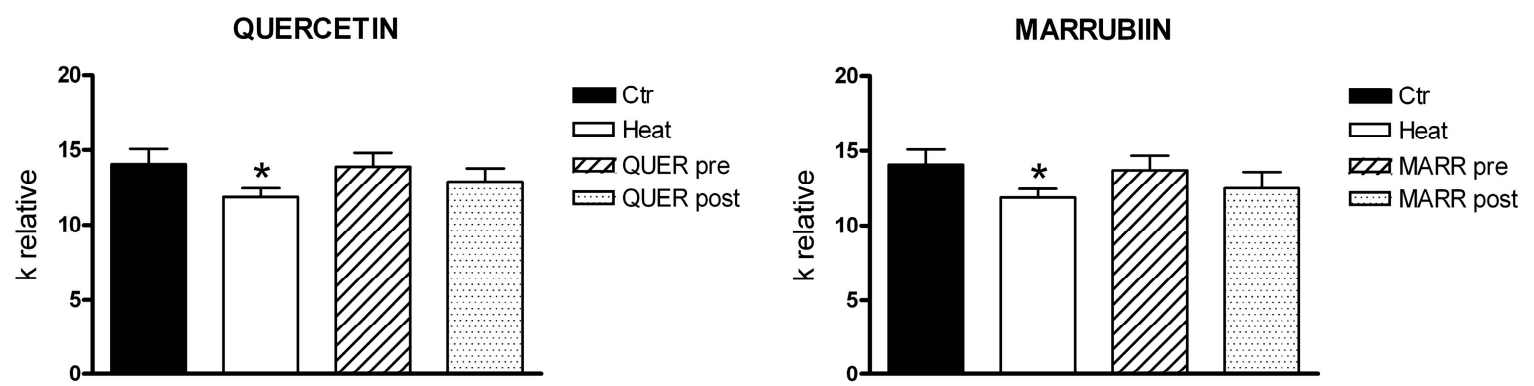

CURCUMIN
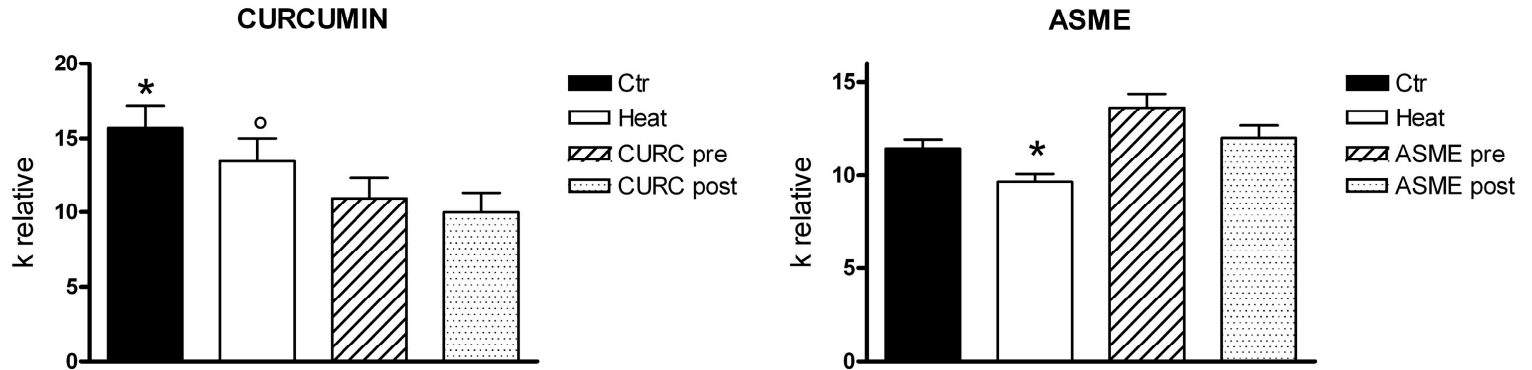

Figure 5. Cont. 

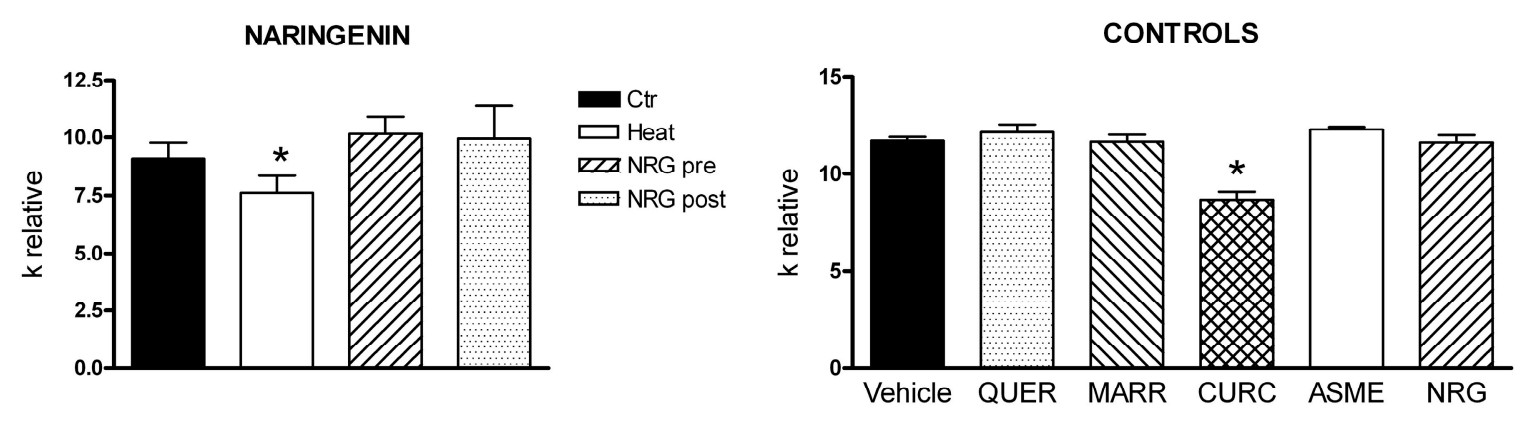

Figure 5. Effect of naringenin (NRG), ASME, quercetin (QUER), marrubiin (MARR), and curcumin (CURC) on the water permeability of HeLa cells in normal and heat-stress conditions. HeLa cells were exposed to a 150 mOsm osmotic gradient in four different conditions: (1) untreated cells (Controls, Ctr); (2) cells treated at $42{ }^{\circ} \mathrm{C}$ for $3 \mathrm{~h}$ (heat-stressed, Heat); (3) heat-stressed cells pre-treated with the antioxidants compounds (NRG, ASME, QUER, MARR, CURC pre); (4) heat-stressed cells post-treated with the antioxidants compounds (NRG, ASME, QUER, MARR, CURC post). The effect of NRG, ASME, QUER, MARR, CURC on water permeability independently on their antioxidant properties was measured in HeLa cells treated at $21^{\circ} \mathrm{C}$ for $3 \mathrm{~h}$ with single compounds at $20 \mu \mathrm{M}$ final concentration. Bars represent the osmotic water permeability of HeLa cells expressed as $k$ relative. Values are means \pm SEM of 4-15 single shots for each of 4-6 different experiments. NRG, ASME, QUER and MARR: ${ }^{*} p<0.05$ vs. Ctr, pre and post (ANOVA for repeated measures, followed by Newman-Keuls' $Q$ test). CURC: ${ }^{*} p<0.05$ vs. Heat, pre and post; ${ }^{\circ} p<0.05$ vs. pre and post (ANOVA for repeated measures, followed by Newman-Keuls' $Q$ test). CONTROLS: ${ }^{*} p<0.05$ vs. vehicle (ANOVA followed by Dunnett $t$ test).

\subsection{Effect of Antioxidant Compounds on the $\mathrm{H}_{2} \mathrm{O}_{2}$ Content in Heat-Stressed HeLa Cells}

The effect of pre- and post-treatment with the antioxidant compounds on the $\mathrm{H}_{2} \mathrm{O}_{2}$ content in heat-stressed HeLa cells was tested by using the CM-H2DCFDA fluorescent probe. Results in Figure 6 show that both pre-treatment and post-treatment with the different compounds reduced the $\mathrm{H}_{2} \mathrm{O}_{2}$ content in heat-stress condition in a statistically significant manner. Moreover, in the pre-treatment condition, QUER was demonstrated the most effective in reducing the $\mathrm{H}_{2} \mathrm{O}_{2}$ intracellular levels even lower than those of control cells.

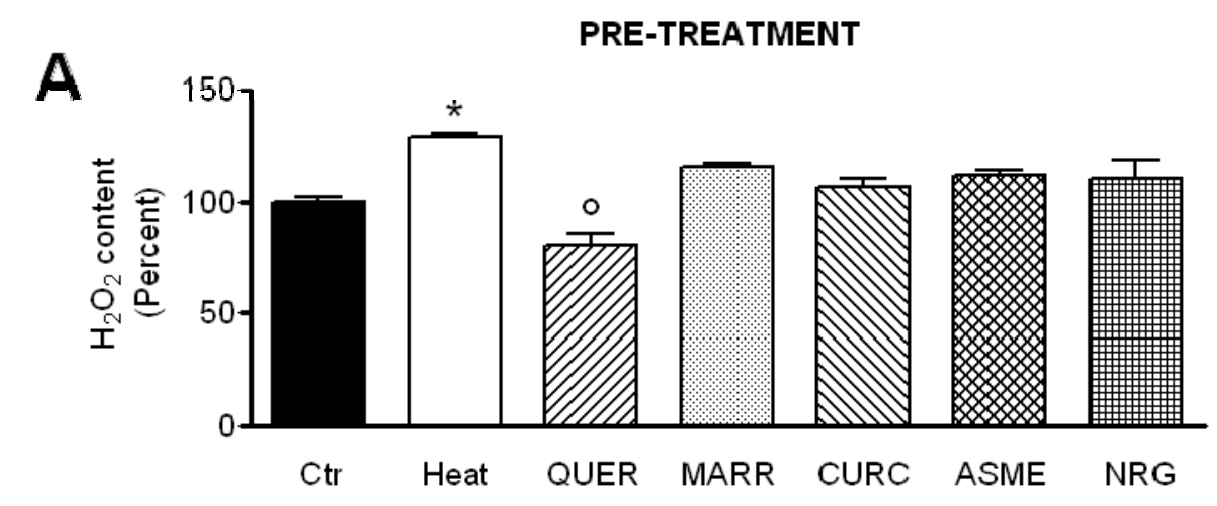

Figure 6. Cont. 


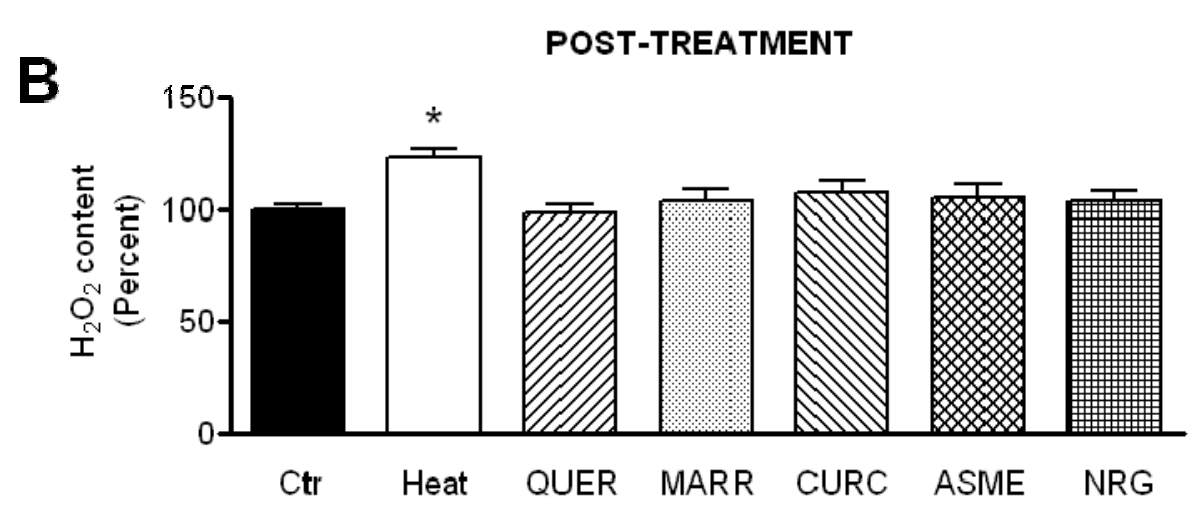

Figure 6. Effect of pre- and post-treatment with quercetin (QUER), marrubiin (MARR), curcumin (CURC), ASME and naringenin (NRG) on the $\mathrm{H}_{2} \mathrm{O}_{2}$ content in heat-stressed HeLa cells. (A) Pre-treatment: hydrogen peroxide $\left(\mathrm{H}_{2} \mathrm{O}_{2}\right)$ was measured using the CM-H2DCFDA reagent (see Materials and Methods) in normal (Ctr) and heat-stressed condition in the presence or in the absence (Heat) of different compounds ( $20 \mu \mathrm{M}$ final concentration); (B) Post-treatment: $\mathrm{H}_{2} \mathrm{O}_{2}$ was measured in HeLa cells in the following conditions: normal (Ctr), heat-stressed (Heat) and heat-stressed cells post-treated with the antioxidants compounds (20 $\mu \mathrm{M}$ final concentration). Bars represent the $\mathrm{H}_{2} \mathrm{O}_{2}$ content in HeLa cells expressed as percent. Values are means $\pm \mathrm{SEM}$ of 4 different experiments. ${ }^{*} p<0.05$ vs. Ctr, QUER, MARR, CURC, ASME, NRG; ${ }^{\circ} p<0.05$ vs. Ctr, Heat, MARR, CURC, ASME, NRG (ANOVA followed by Newman-Keuls' $Q$ test).

\section{Discussion}

As a part of our on-going research, we selected compounds of Figure 1 in order to understand the structural features responsible for the interaction with AQPs. We selected five antioxidant compounds which are characterized by different scaffolds, and potentially, different aromatic substitutions. As a first step of our work, we evaluate their FRS properties by a chemical assay (DPPH) widely used as primary screening of antioxidant activity of natural compounds. All compounds showed FRS activity, even with different profiles, with the only exception of MARR endowed with poor FRS properties. We decided to further investigate all compounds to understand their beneficial role in counteracting the oxidative stress.

Firstly, we demonstrated in HeLa cells the expression of multiple AQPs at both mRNA and protein level: AQP1, 3, 8, and 11 (Figure 3). Among these, AQP3 and AQP8 were found to facilitate the $\mathrm{H}_{2} \mathrm{O}_{2}$ transmembrane transport in different experimental conditions, whereas AQP11 was suggested to have a peroxiporin function, though not directly demonstrated [12,14-16,18,21-24]. Then, we have studied the effect of some antioxidant compounds on the osmotic water permeability of HeLa cells in the presence of oxidative stress condition. Cellular oxidative stress was found to inhibit the permeability to water, as previously observed for AQP8 $[14,24,25]$. The presence of QUER, NRG, ASME, and MARR, during or after heat-treatment, was able to prevent or restore the water permeability decrease (Figures 4 and 5). Actually, water movement changes could be considered representative of an $\mathrm{H}_{2} \mathrm{O}_{2}$ flux variation [14,25]. A different behavior was evidenced for CURC (Figures 4B and 5). The effect of the compounds was also tested in the absence of oxidative stress, in the hypothesis of their possible direct channel modulation. Surprisingly, CURC significantly inhibited the water permeability, while other compounds were ineffective (Figure 5, CONTROLS).

The antioxidant efficacy of all compounds was then evaluated by measuring the content of $\mathrm{H}_{2} \mathrm{O}_{2}$ in heat-stressed cells. Pre-treatment and post-treatment with all compounds significantly reduced the $\mathrm{H}_{2} \mathrm{O}_{2}$ content in heat-stressed cells. Moreover, in the pre-treatment condition, QUER resulted in the most effective in reducing the $\mathrm{H}_{2} \mathrm{O}_{2}$ intracellular levels, even lower than those of control cells (Figure 6). It is worth noting that also in the DPPH assay, QUER showed relative high potency in comparison to other compounds (Figure 2). 
The results are not surprising, in light of recent findings on the beneficial effect of polyphenols, and phytochemical compounds in general, in modulating AQPs gene expression (for a complete review see [48]). Particularly, Kumar et al. found that QUER treatment of streptozotocin-induced diabetic rats prevents the retina neurodegeneration, at least in part by normalizing the expression of AQP4 (inhibition) [49], even if it is not clear if this effect derives from its antioxidant activity or by preventing retinal edema. Conversely, QUER increased AQP5 expression, and decreased oxidative stress and inflammation induced by radiation exposure, in impaired salivary secretion by exposure to radiation [50]. This result is consistent with the function as peroxiporin of AQP5 recently demonstrated [19].

Polyphenols have been shown to modulate AQPs expression, but so far, there was no data about their effects on the osmotic water permeability, or on the direct interaction with AQP/AQPs [48]. The results herein presented, suggest that not only the polyphenols QUER and NRG, but also ASME and MARR, are able to normalize the water permeability, which in turn determines the removal of $\mathrm{H}_{2} \mathrm{O}_{2}$ and oxidative stress resolution. It has been shown that oxidative stress conditions inhibit AQP8-mediated $\mathrm{H}_{2} \mathrm{O}_{2}$ scavenging, and that, in a vicious circle, contribute to worsening the condition [14]. Neither $\mathrm{H}_{2} \mathrm{O}_{2}$ nor water uptake is impaired in stressed cells expressing a mutant C53S AQP8 that do not accumulate intracellular ROS, and are more resistant to stress-induced growth arrest and death.

As regards CURC, we observed a considerably different behavior compared with other substances tested. Despite that it demonstrated clear antioxidant properties (Figures 2 and 6), CURC did not protect nor restore the AQPs' permeability properties in heat-treated cells, but showed a direct inhibitory effect on AQP/AQPs (Figures $4 \mathrm{~B}$ and 5). Few potential AQP inhibitors have been identified to date, and some of them have low specificity and high toxicity (see $\mathrm{Hg}^{2+}$ and cysteine-targeting heavy metal-based inhibitors in general) [26]. Accordingly, the identification of a new and non-toxic molecule is of particular interest, since AQPs has been proposed as potential "druggable" targets in several pathophysiological conditions [26]. AQPs' druggability has been recently demonstrated. Molecular docking computations identified a cavity close complementary of arbidol, berbamine, and tamarixetin (a quercetin metabolite) on the extracellular AQP4 surface [51]. Successively, molecular dynamics and molecular interaction fields have allowed for precise identification of a cavity, close to loop A of the AQP4, used by the above-mentioned compounds as a putative binding site [52]. As a whole, these results strongly suggest the possibility, also, for other AQPs to be bound by drug-like molecules, CURC being a valid candidate. The effect of CURC is seemingly paradoxical, because it has well-documented antioxidant properties, but at the same time, inhibits the functioning of AQPs, that in turn heightens the oxidative stress. It could be speculated that CURC may reduce $\mathrm{H}_{2} \mathrm{O}_{2}$ entry into the cell (AQP-mediated) that is produced by oxidative stress through NOX or dual oxidase extracellular activity, or from circulating ROS. However, the effect of CURC in lowering the $\mathrm{H}_{2} \mathrm{O}_{2}$ intracellular levels in heat-stress conditions (Figure 6) derives to other intracellular antioxidant properties of the compounds: the direct ROS scavenging, the metal chelating, and the modulation of cytoprotective and antioxidant proteins via the expression of the transcription factor nuclear factor-erythroid-2-related factor 2 [53]. The antioxidant, neuro-protective, anti-inflammatory, anti-cancer properties of CURC have been recognized for millennia, and it is commonly used in traditional medicine [54]. It has been demonstrated that there is a downregulation of AQP4 (normalization) after CURC administration in different neurological injury and brain damage models like: traumatic brain injury, hypoxia-ischemic brain damage, hypoxia-hypercapnia-induced brain damage, and spinal cord injury [55-58]. In mice with intracerebral hemorrhage, CURC dose-dependently decreased AQP4 and AQP9, but not AQP1 expression, through the NF-KB signaling pathway [59]. CURC treatment was also found to downregulate AQP1 in rat choroid plexus cells, useful to reduce cerebrospinal fluid production in some pathophysiological conditions [60], and AQP3 expression in human ovarian cancer cells [61]. However, the biological functions of CURC are far from fully clarified, and sometimes appear conflicting [54]. In conclusion, 
all the compounds analyzed have confirmed their antioxidant capacity. QUER, NRG, ASME, and MARR are able to protect or restore the AQP-mediated $\mathrm{H}_{2} \mathrm{O}_{2}$ cellular elimination, while CURC seems to prevent $\mathrm{H}_{2} \mathrm{O}_{2}$ cellular entry. The results presented here suggest the possibility to chemically regulate the pore gating of peroxiporins, and provide a new direction to the development of new therapeutic treatments for cancer, degenerative diseases, as well as in ageing.

\section{Materials and Methods}

\subsection{Cell Culture}

HeLa cells were routinely grown in plastic tissue culture flasks using Dulbecco's modified minimal essential medium high glucose, supplemented with $10 \%$ fetal bovine serum, $1 \%$ L-glutamine, $1 \%$ penicillin and streptomycin, and maintained at $37{ }^{\circ} \mathrm{C}$ in a humidified atmosphere of $5 \% \mathrm{CO}_{2}$, $95 \%$ air.

\subsection{RNA Isolation and RT-PCR}

Total RNA was extracted from HeLa cells using QIAzol Lysis Reagent (Qiagen SpA, Milan, Italy), and reverse transcription was performed according to Laforenza et al. [62]. cDNA amplification was performed by GoTaq ${ }^{\circledR}$ Flexi DNA Polymerase (Promega, Milano, Italy), as previously described [62]. The primers used for amplification are listed in the Table 2. The PCR protocol consisted of an initial denaturation of $3 \mathrm{~min}$ at $95^{\circ} \mathrm{C}$ followed by 35 cycles of denaturation at $96^{\circ} \mathrm{C}$ for $30 \mathrm{~s}$, annealing (see TM in Table 1) for $30 \mathrm{~s}$, and extension at $72{ }^{\circ} \mathrm{C}$ for $30 \mathrm{~s}$. Reverse transcription was always performed both either in the presence (positive) or in the absence (negative control) of reverse transcriptase enzyme. PCR products were separated on a $3 \%$ Nusieve ${ }^{\circledR}(2: 1)$ gel agarose, stained with ethidium bromide, and acquired with the Image Master VDS (GE Healthcare, Milano, Italy). The molecular weight of the PCR products was compared with the DNA molecular weight marker VIII (Roche Molecular Biochemicals, Monza, Italy).

Table 2. Primer sequences used for real time reverse transcription/polymerase chain reaction.

\begin{tabular}{|c|c|c|c|c|c|}
\hline Gene & & Primer Sequences & Size (bp) & $\mathrm{TM}\left({ }^{\circ} \mathrm{C}\right)$ & Accession Number \\
\hline$A Q P 1$ & $\begin{array}{l}\text { Forward } \\
\text { Reverse }\end{array}$ & $\begin{array}{l}\text { 5'-TTAACCCTGCTCGGTCCTTT-3' }^{\prime} \\
5^{\prime} \text {-TTCATCTCCACCCTGGAGTT-3' }\end{array}$ & 229 & 60 & NM_198098 \\
\hline$A Q P 2$ & $\begin{array}{l}\text { Forward } \\
\text { Reverse }\end{array}$ & $\begin{array}{c}\text { 5'-CCACACTCCTCTTCGTCTTCTT-3' } \\
\text { 5'-CCCAGTGGTCATCAAATTTGCC-3' }^{\prime}\end{array}$ & 552 & 60 & NM_000486 \\
\hline$A Q P 3$ & $\begin{array}{l}\text { Forward } \\
\text { Reverse }\end{array}$ & $\begin{array}{l}\text { 5'-TTTGCTACCTACCCCTCTGG-3' }^{\prime} \\
5^{\prime} \text {-GGCCAGCTTCACATTCTCTT-3' }\end{array}$ & 414 & 60 & NM_004925 \\
\hline$A Q P 4$ & $\begin{array}{l}\text { Forward } \\
\text { Reverse }\end{array}$ & $\begin{array}{l}\text { 5'-GGTCTCCTGGTTGAGTTGAT-3' } \\
5^{\prime} \text {-TTGTTTGCTGGGCAGCTTTG-3' }\end{array}$ & 346 & 60 & NM_004028 \\
\hline AQP5 & $\begin{array}{l}\text { Forward } \\
\text { Reverse }\end{array}$ & $\begin{array}{l}\text { 5'-GAGCTGATTCTGACCTTCCA-3' } \\
\text { 5'-AGGCTCATACGTGCCTTTGA-3' }^{\prime}\end{array}$ & 333 & 58 & NM_001651 \\
\hline AQP6 & $\begin{array}{l}\text { Forward } \\
\text { Reverse }\end{array}$ & 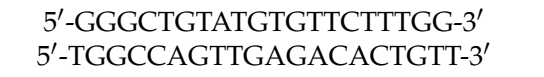 & 326 & 60 & NM_001652 \\
\hline$A Q P 7$ & Hs_AQP7_ & SG QuantiTect Primer Assay QT00067592 * & 139 & 60 & NM_001170 \\
\hline$A Q P 8$ & $\begin{array}{l}\text { Forward } \\
\text { Reverse }\end{array}$ & $\begin{array}{l}\text { 5'-AGGAGAGGTTCTGGAATGCA-3' } \\
5^{\prime} \text {-AGTGGAAGTTCCAGTGGTTG-3' }\end{array}$ & 282 & 60 & NM_001169 \\
\hline$A Q P 9$ & $\begin{array}{l}\text { Forward } \\
\text { Reverse }\end{array}$ & $\begin{array}{l}\text { 5'-AAGCTTCAAGCAGAGACTGG-3' } \\
5^{\prime} \text {-GGAGCTGGGTATGTTGCAAA-3' }\end{array}$ & 432 & 60 & NM_020980 \\
\hline$A Q P 10$ & $\begin{array}{l}\text { Forward } \\
\text { Reverse }\end{array}$ & $\begin{array}{l}\text { 5'-CCCTATCTGTCCCTGAACAA-3' } \\
5^{\prime} \text {-CCAGGTTCTGGCACATTAAC-3 }\end{array}$ & 554 & 60 & NM_080429 \\
\hline$A Q P 11$ & $\begin{array}{l}\text { Forward } \\
\text { Reverse }\end{array}$ & $\begin{array}{l}\text { 5'-GGCTGCACTCATCACCTTTT-3' } \\
5^{\prime} \text {-GGAGCCAGCCAGTATACTAT-3' }\end{array}$ & 141 & 58 & NM_173039 \\
\hline
\end{tabular}




\subsection{Immunoblotting}

HeLa cells were treated as previously described [63]. Solubilized proteins $(30 \mu \mathrm{g})$ were subjected to $12.5 \%$ SDS-polyacrylamide gel electrophoresis, and transferred to Hybond-P PVDF membrane (GE Healthcare) by electroelution. The membranes were incubated overnight with anti-AQP1 rabbit polyclonal IgG affinity pure (AQP1-A, 1:800; Alpha Diagnostics Intl. Inc., San Antonio, TX, USA), anti-AQP3 rabbit polyclonal IgG (sc-20811, 1:300; Santa Cruz Biotechnology, Inc., Heidelberg, Germany), anti-AQP8 rabbit polyclonal IgG affinity pure (AQP8-A, 1:500; Alpha Diagnostics Intl. Inc.; sc-81870, 1:500; Santa Cruz Biotechnology, Inc., Heidelberg, Germany, anti-AQP9 mouse polyclonal IgG (sc-74409, 1:300; Santa Cruz Biotechnology, Inc.), and affinity purified rabbit anti-human AQP11 polyclonal antibody (AP5805b, 1:500; Abgent Inc., San Diego, CA, USA), previously characterized [25,64-66]. The membranes were washed and incubated for $1 \mathrm{~h}$ with goat anti-rabbit IgG antibody, peroxidase conjugated (AP132P; Millipore part of Merck S.p.a., Vimodrone, Italy) or with peroxidase-conjugated mouse IgG from Dakocytomation (P0260), diluted 1:100,000 in blocking solution. The bands were detected with ECL ${ }^{\text {TM }}$ Select Western blotting detection system (GE Healthcare). Prestained molecular weight markers (Precision Plus Protein ${ }^{\mathrm{TM}}$ Dual Color Standards, \#1610374, Bio-Rad, Segrate, Italy) were used to estimate the molecular weight of the bands.

\subsection{DPPH Assay}

The FRS of the extracts was determined by using a DPPH assay [39]. QUER was used as a standard. Briefly, all compounds were dissolved in $\mathrm{MeOH}$, and then serially diluted in the same solvent until the target concentrations were reached. Each compound was tested at different concentrations, in the range allowed by their solubility. FRS was expressed as a percent compared with the reference compound, consisting of $3.9 \mathrm{~mL}$ of DPPH solution and $100 \mu \mathrm{L}$ of methanol. The percent inhibition of the DPPH radical by the test solution was calculated using the following formula:

$$
\text { FRS } \%=[(\text { Abs control }- \text { Abs sample }) / \text { Abs control }] \times 100
$$

The analyses were carried out in triplicate, and results are expressed as mean \pm SEM.

\subsection{Water Permeability Measurements}

Osmotic water permeability of the HeLa cells was measured by stopped-flow light scattering method $[64,66]$. Briefly, the experiments were carried out at room temperature on a stopped flow apparatus (RX2000, Applied Photophysics, Leatherhead, UK) with a pneumatic drive accessory (DA.1, Applied Photophysics) coupled with a Varian Cary 50 spectrometer (Varian Australia Pty Ltd., Mulgrave, Australia). Scattered light intensity with a dead time of $6 \mathrm{~ms}$ was recorded at a wavelength of $450 \mathrm{~nm}$. The time course of cell swelling caused by exposure to the hypotonic gradient $(150 \mathrm{mOsm} / \mathrm{L})$ was measured for $60 \mathrm{~s}$ at the acquisition rate of one reading $/ 0.0125 \mathrm{~s}$. Cells behaved as perfect osmometers, the gradient determined an osmotic water entry, cell swelling, and decreased light scattering. The initial rate constant of cells volume changes $(k)$ was obtained by fitting the points of the time course of light scattering with a one phase exponential decay equation, calculated by computerized least squares regression (GraphPad Prism 4.00, La Jolla, CA, USA, 2003). To study the effect of oxidative stress on water permeability and the antioxidant effect of different natural compounds, HeLa cells were divided into four groups: (1) controls, cells left at room temperature $\left(21^{\circ} \mathrm{C}\right) ;(2)$ heat-stressed cells, cells subjected to heat-shock treatment by placing them in a water thermostatic and shacking bath at $42{ }^{\circ} \mathrm{C}$ for $3 \mathrm{~h}$; (3) heat-stressed cells pre-treated, cells incubated in a water thermostatic and shacking bath at $42{ }^{\circ} \mathrm{C}$ for $3 \mathrm{~h}$ together with the antioxidants compounds NRG, ASME, QUER, MARR, and CURC at $20 \mu \mathrm{M}$ final concentration (dissolved in methanol); (4) heat-stressed cells post-treated, cells incubated in a water thermostatic and shacking bath at $42{ }^{\circ} \mathrm{C}$ for $3 \mathrm{~h}$, and then further incubated at $21^{\circ} \mathrm{C}$ for $30 \mathrm{~min}$ with the antioxidant compounds. To study the effectiveness of the analyzed compounds to 
affect the AQP gating independently of their antioxidant properties, HeLa cells were treated in the presence and in the absence of the compounds by incubating at $21^{\circ} \mathrm{C}$ for $3 \mathrm{~h}$.

\subsection{Hydrogen Peroxide Measurements}

Hydrogen peroxide levels in HeLa cells were measured by a fluorescence method using the 5(and-6)-chloromethyl-2', $7^{\prime}$-dichlorodihydro-fluorescein diacetate, acetyl ester reagent (CM-H2DCFDA) (Invitrogen). Briefly, cells were centrifuged at $200 \mathrm{rcf}$ for $5 \mathrm{~min}$. The cell pellet was resuspended in PBS and CM-H2DCFDA reagent was added at $5 \mathrm{mM}$ final concentration and incubated for $1 \mathrm{~h}$ at room temperature. Thereafter, cells were centrifuged again, and the pellet resuspended in PBS. Hydrogen peroxide levels were measured in the experimental conditions described above by using a CLARIOstar $^{\circledR}$ microplate reader (BMG LABTECH, Ortenberg, Germany).

\subsection{Protein Content}

The protein content was determined with the Bradford method [67], using bovine serum albumin as standard.

\subsection{Statistics}

All data were expressed as means \pm SEM (Standard Error Mean). The significance of the differences of the means were evaluated by using one-way ANOVA, followed by Newman-Keuls' $Q$ test, or Student's $t$ test. All statistical tests were carried out with GraphPad Prism 4.00, 2003.

Acknowledgments: This work has been funded by University of Pavia FAR 2012.

Author Contributions: Umberto Laforenza conceived and designed the experiments; Giorgia Pellavio, Umberto Laforenza, Marta Rui, Laura Caliogna performed the experiments; Umberto Laforenza, Emanuela Martino and Giulia Gastaldi analyzed the data; Giulia Gastaldi contributed reagents/materials/analysis tools; Simona Collina and Umberto Laforenza wrote the paper.

Conflicts of Interest: The authors declare no conflict of interest.

\section{Abbreviations}

$\begin{array}{ll}\mathrm{H}_{2} \mathrm{O}_{2} & \text { Hydrogen peroxide } \\ \text { ROS } & \text { Reactive oxygen species } \\ \text { SOD } & \text { Superoxide dismutase } \\ \text { NOX } & \text { NADPH oxidases } \\ \text { AQP } & \text { Aquaporin } \\ \text { CM-H2DCFDA } & \text { 5-(and-6)-chloromethyl-2' }{ }^{\prime} 7^{\prime} \text {-dichlorodihydrofluorescein diacetate, acetyl ester } \\ \text { ASME } & \text { (R)-aloesaponol III-8 methyl ether } \\ \text { NRG } & \text { Naringenin } \\ \text { QUER } & \text { Quercetin } \\ \text { MARR } & \text { Marrubiin } \\ \text { CURC } & \text { Curcumin } \\ \text { FRS } & \text { Free radical scavenging } \\ \text { DPPH } & \alpha, \alpha \text {-diphenyl- } \beta \text {-picrylhydrazyl } \\ \text { SEM } & \text { Standard error mean }\end{array}$

\section{References}

1. Agarwal, A.; Virk, G.; Ong, C.; du Plessis, S.S. Effect of oxidative stress on male reproduction. World J. Men's Health 2014, 32, 1-17. [CrossRef] [PubMed]

2. Alfadda, A.A.; Sallam, R.M. Reactive oxygen species in health and disease. J. Biomed. Biotechnol. 2012, 2012, 936486. [CrossRef] [PubMed]

3. He, F.; Li, J.; Liu, Z.; Chuang, C.C.; Yang, W.; Zuo, L. Redox mechanism of reactive oxygen species in exercise. Front. Physiol. 2016, 7, 486. [CrossRef] [PubMed] 
4. Kakihana, T.; Nagata, K.; Sitia, R. Peroxides and peroxidases in the endoplasmic reticulum: Integrating redox homeostasis and oxidative folding. Antioxid. Redox Signal. 2012, 16, 763-771. [CrossRef] [PubMed]

5. Sies, H. Role of metabolic $\mathrm{H}_{2} \mathrm{O}_{2}$ generation: Redox signaling and oxidative stress. J. Biol. Chem. 2014, 289, 8735-8741. [CrossRef] [PubMed]

6. Bienert, G.P.; Schjoerring, J.K.; Jahn, T.P. Membrane transport of hydrogen peroxide. Biochim. Biophys. Acta 2006, 1758, 994-1003. [CrossRef] [PubMed]

7. Sies, H. Hydrogen peroxide as a central redox signaling molecule in physiological oxidative stress: Oxidative eustress. Redox Biol. 2017, 11, 613-619. [CrossRef] [PubMed]

8. Henzler, T.; Steudle, E. Transport and metabolic degradation of hydrogen peroxide in Chara corallina: Model calculations and measurements with the pressure probe suggest transport of $\mathrm{H}_{2} \mathrm{O}_{2}$ across water channels. J. Exp. Bot. 2000, 51, 2053-2066. [CrossRef] [PubMed]

9. Laforenza, U.; Bottino, C.; Gastaldi, G. Mammalian aquaglyceroporin function in metabolism. Biochim. Biophys. Acta 2016, 1858, 1-11. [CrossRef] [PubMed]

10. King, L.S.; Kozono, D.; Agre, P. From structure to disease: The evolving tale of aquaporin biology. Nat. Rev. Mol. Cell Biol. 2004, 5, 687-698. [CrossRef] [PubMed]

11. Benga, G. Foreword to the special issue on water channel proteins (aquaporins and relatives) in health and disease: 25 years after the discovery of the first water channel protein, later called aquaporin 1. Mol. Asp. Med. 2012, 33, 511-513. [CrossRef] [PubMed]

12. Bienert, G.P.; Møller, A.L.; Kristiansen, K.A.; Schulz, A.; Møller, I.M.; Schjoerring, J.K.; Jahn, T.P. Specific aquaporins facilitate the diffusion of hydrogen peroxide across membranes. J. Biol. Chem. 2007, 282, 1183-1192. [CrossRef] [PubMed]

13. Bienert, G.P.; Chaumont, F. Aquaporin-facilitated transmembrane diffusion of hydrogen peroxide. Biochim. Biophys. Acta 2014, 1840, 1596-1604. [CrossRef] [PubMed]

14. Medraño-Fernandez, I.; Bestetti, S.; Bertolotti, M.; Bienert, G.P.; Bottino, C.; Laforenza, U.; Rubartelli, A.; Sitia, R. Stress regulates Aquaporin-8 permeability to impact cell growth and survival. Antioxid. Redox Signal. 2016, 24, 1031-1044. [CrossRef] [PubMed]

15. Miller, E.W.; Dickinson, B.C.; Chang, C.J. Aquaporin-3 mediates hydrogen peroxide uptake to regulate downstream intracellular signaling. Proc. Natl. Acad. Sci. USA 2010, 107, 15681-15686. [CrossRef] [PubMed]

16. Hara-Chikuma, M.; Chikuma, S.; Sugiyama, Y.; Kabashima, K.; Verkman, A.S.; Inoue, S.; Miyachi, Y. Chemokine-dependent $\mathrm{T}$ cell migration requires aquaporin-3-mediated hydrogen peroxide uptake. J. Exp. Med. 2012, 209, 1743-1752. [CrossRef] [PubMed]

17. Watanabe, S.; Moniaga, C.S.; Nielsen, S.; Hara-Chikuma, M. Aquaporin-9 facilitates membrane transport of hydrogen peroxide in mammalian cells. Biochem. Biophys. Res. Commun. 2016, 471, 191-197. [CrossRef] [PubMed]

18. Thiagarajah, J.R.; Chang, J.; Goettel, J.A.; Verkman, A.S.; Lencer, W.I. Aquaporin-3 mediates hydrogen peroxide-dependent responses to environmental stress in colonic epithelia. Proc. Natl. Acad. Sci. USA 2017, 114, 568-573. [CrossRef] [PubMed]

19. Rodrigues, C.; Mósca, A.F.; Martins, A.P.; Nobre, T.; Prista, C.; Antunes, F.; Cipak Gasparovic, A.; Soveral, G. Rat Aquaporin-5 is $\mathrm{pH}-$ Gated induced by phosphorylation and is implicated in oxidative stress. Int. J. Mol. Sci. 2016, 17, 2090. [CrossRef] [PubMed]

20. Almasalmeh, A.; Krenc, D.; Wu, B.; Beitz, E. Structural determinants of the hydrogen peroxide permeability of aquaporins. FEBS J. 2014, 281, 647-656. [CrossRef] [PubMed]

21. Atochina-Vasserman, E.N.; Biktasova, A.; Abramova, E.; Cheng, D.S.; Polosukhin, V.V.; Tanjore, H.; Takahashi, S.; Sonoda, H.; Foye, L.; Venkov, C.; et al. Aquaporin 11 insufficiency modulates kidney susceptibility to oxidative stress. Am. J. Physiol. Ren. Physiol. 2013, 304, 1295-1307. [CrossRef] [PubMed]

22. Hara-Chikuma, M.; Watanabe, S.; Satooka, H. Involvement of aquaporin-3 in epidermal growth factor receptor signaling via hydrogen peroxide transport in cancer cells. Biochem. Biophys. Res. Commun. 2016, 471, 603-609. [CrossRef] [PubMed]

23. Satooka, H.; Hara-Chikuma, M. Aquaporin-3 controls breast cancer cell migration by regulating hydrogen peroxide transport and its downstream cell signaling. Mol. Cell. Biol. 2016, 36, 1206-1218. [CrossRef] [PubMed] 
24. Bertolotti, M.; Bestetti, S.; García-Manteiga, J.M.; Medraño-Fernandez, I.; Dal Mas, A.; Malosio, M.L.; Sitia, R. Tyrosine kinase signal modulation: A matter of $\mathrm{H}_{2} \mathrm{O}_{2}$ membrane permeability? Antioxid. Redox Signal. 2013, 19, 1447-1451. [CrossRef] [PubMed]

25. Laforenza, U.; Pellavio, G.; Marchetti, A.L.; Omes, C.; Todaro, F.; Gastaldi, G. Aquaporin-mediated water and hydrogen peroxide transport is involved in normal human spermatozoa functioning. Int. J. Mol. Sci. 2016, 18, 66. [CrossRef] [PubMed]

26. Verkman, A.S.; Anderson, M.O.; Papadopoulos, M.C. Aquaporins: Important but elusive drug targets. Nat. Rev. Drug Discov. 2014, 13, 259-277. [CrossRef] [PubMed]

27. Beitz, E.; Golldack, A.; Rothert, M.; von Bülow, J. Challenges and achievements in the therapeutic modulation of aquaporin functionality. Pharmacol. Ther. 2015, 155, 22-35. [CrossRef] [PubMed]

28. Gaggeri, R.; Rossi, D.; Collina, S.; Mannucci, B.; Baierl, M.; Juza, M. Quick development of an analytical enantioselective high performance liquid chromatography separation and preparative scale-up for the flavonoid Naringenin. J. Chromatogr. A 2011, 1218, 5414-5422. [CrossRef] [PubMed]

29. Gaggeri, R.; Rossi, D.; Christodoulou, M.S.; Passarella, D.; Leoni, F.; Azzolina, O.; Collina, S. Chiral flavanones from amygdalus lycioides spach: Structural elucidation and identification of tnfalpha inhibitors by bioactivity-guided fractionation. Molecules 2012, 17, 1665-1674. [CrossRef] [PubMed]

30. Oboh, G.; Ademosun, A.O.; Ogunsuyi, O.B. Quercetin and its role in chronic diseases. Adv. Exp. Med. Biol. 2016, 929, 377-387. [PubMed]

31. Li, Y.; Yao, J.; Han, C.; Yang, J.; Chaudhry, M.T.; Wang, S.; Liu, H.; Yin, Y. Quercetin, inflammation and immunity. Nutrients 2016, 8, 167. [CrossRef] [PubMed]

32. Wang, W.; Sun, C.; Mao, L.; Ma, P.; Liu, F.; Yang, J.; Gao, Y. The biological activities, chemical stability, metabolism and delivery systems of quercetin: A review. Trends Food Sci. Technol. 2016, 56, 21-38. [CrossRef]

33. Haghi, A.; Azimi, H.; Rahimi, R. A Comprehensive review on pharmacotherapeutics of three phytochemicals, curcumin, quercetin, and allicin, in the treatment of gastric cancer. J. Gastrointest. Cancer 2017, 48, 314-320. [CrossRef] [PubMed]

34. Rani, N.; Bharti, S.; Krishnamurthy, B.; Bhatia, J.; Sharma, C.; Kamal, M.A.; Ojha, S.; Arya, D.S. Pharmacological properties and therapeutic potential of naringenin: A citrus flavonoid of pharmaceutical promise. Curr. Pharm. Des. 2016, 22, 4341-4359. [CrossRef] [PubMed]

35. Du, G.; Jin, L.; Han, X.; Song, Z.; Zhang, H.; Liang, W. Naringenin: A potential immunomodulator for inhibiting lung fibrosis and metastasis. Cancer Res. 2009, 69, 3205-3212. [CrossRef] [PubMed]

36. Galati, G.; Sabzevari, O.; Wilson, J.X.; O’Brien, P.J. Prooxidant activity and cellular effects of the phenoxyl radicals of dietary flavonoids and other polyphenolics. Toxicology 2002, 177, 91-104. [CrossRef]

37. Bodet, C.; La, V.D.; Epifano, F.; Grenier, D. Naringenin has anti-inflammatory properties in macrophage and ex vivo human whole-blood models. J. Periodontal Res. 2008, 43, 400-407. [CrossRef] [PubMed]

38. Shinkaruk, S.; Lamothe, V.; Schmitter, J.M.; Manach, C.; Morand, C.; Berard, A.; Bennetau, B.; Bennetau-Pelissero, C. Development and validation of two new sensitive ELISAs for Hesperetin and Naringenin in biological fluids. Food Chem. 2010, 118, 472-481. [CrossRef]

39. Rossi, D.; Ahmed, K.M.; Gaggeri, R.; Della Volpe, S.; Maggi, L.; Mazzeo, G.; Longhi, G.; Abbate, S.; Corana, F.; Martino, E.; et al. (R)-(-)-Aloesaponol III 8-Methyl Ether from Eremurus persicus: A Novel Compound against Leishmaniosis. Molecules 2017, 22, 519. [CrossRef] [PubMed]

40. Panahi, Y.; Ahmadi, Y.; Teymouri, M.; Johnston, T.P.; Sahebkar, A. Curcumin as a potential candidate for treating hyperlipidemia: A review of cellular and metabolic mechanisms. J. Cell. Physiol. 2018, 233, 141-152. [CrossRef] [PubMed]

41. Carvalho, L.F.; Silva, A.M.F.; Carvalho, A.A. The use of antioxidant agents for chemotherapy-induced peripheral neuropathy treatment in animal models. Clin. Exp. Pharmacol. Physiol. 2017, 44, 971-979. [CrossRef] [PubMed]

42. Adiwidjaja, J.; McLachlan, A.J.; Boddy, A.V. Curcumin as a clinically-promising anti-cancer agent: Pharmacokinetics and drug interactions. Expert Opin. Drug Metab. Toxicol. 2017, 13, 953-972. [CrossRef] [PubMed]

43. Beukes, N.; Levendal, R.A.; Frost, C.L. Selected terpenoids from medicinal plants modulate endoplasmic reticulum stress in metabolic disorders. J. Pharm. Pharmacol. 2014, 66, 1505-1525. [CrossRef] [PubMed]

44. Popoola, O.K.; Elbagory, A.M.; Ameer, F.; Hussein, A.A. Marrubiin. Molecules 2013, 18, 9049-9060. [CrossRef] [PubMed] 
45. Amri, B.; Ben Kaab, S.; Gouia, H.; Martino, E.; Collina, S.; Ben Kaâb, L.B. Copper-induced changes in nutrient uptake, enzymatic and non-enzymatic antioxidant systems in horehound (Marrubium vulgare L.). Bot. Sci. 2017, 95, 565-575. [CrossRef]

46. Nguyen, P.D.; Sayagh, C.; Borie, N.; Lavaud, C. Anti-radical flavonol glycosides from the aerial parts of Cleome chelidonii L.f. Phytochemistry 2017, 142, 30-37. [CrossRef] [PubMed]

47. Flanagan, S.W.; Moseley, P.L.; Buettner, G.R. Increased flux of free radicals in cells subjected to hyperthermia: Detection by electron paramagnetic resonance spin trapping. FEBS Lett. 1998, 431, 285-286. [CrossRef]

48. Cataldo, I.; Maggio, A.; Gena, P.; de Bari, O.; Tamma, G.; Portincasa, P.; Calamita, G. Modulation of Aquaporins by dietary patterns and plant bioactive compounds. Curr. Med. Chem. 2017. [CrossRef]

49. Kumar, B.; Gupta, S.K.; Nag, T.C.; Srivastava, S.; Saxena, R.; Jha, K.A.; Srinivasan, B.P. Retinal neuroprotective effects of quercetin in streptozotocin-induced diabetic rats. Exp. Eye Res. 2014, 125, 193-202. [CrossRef] [PubMed]

50. Takahashi, A.; Inoue, H.; Mishima, K.; Ide, F.; Nakayama, R.; Hasaka, A.; Ryo, K.; Ito, Y.; Sakurai, T.; Hasegawa, Y.; et al. Evaluation of the effects of quercetin on damaged salivary secretion. PLoS ONE 2015, 10, e0116008. [CrossRef] [PubMed]

51. Tradtrantip, L.; Zhang, H.; Anderson, M.O.; Saadoun, S.; Phuan, P.W.; Papadopoulos, M.C.; Bennett, J.L.; Verkman, A.S. Small-molecule inhibitors of NMO-IgG binding to aquaporin-4 reduce astrocyte cytotoxicity in neuromyelitis optica. FASEB J. 2012, 26, 2197-2208. [CrossRef] [PubMed]

52. Mangiatordi, G.F.; Alberga, D.; Siragusa, L.; Goracci, L.; Lattanzi, G.; Nicolotti, O. Challenging AQP4 druggability for NMO-IgG antibody binding using molecular dynamics and molecular interaction fields. Biochim. Biophys. Acta 2015, 1848, 1462-1471. [CrossRef] [PubMed]

53. Cai, W.; Zhang, B.; Duan, D.; Wu, J.; Fang, J. Curcumin targeting the thioredoxin system elevates oxidative stress in HeLa cells. Toxicol. Appl. Pharmacol. 2012, 262, 341-348. [CrossRef] [PubMed]

54. Fiorentini, D.; Zambonin, L.; Dalla Sega, F.V.; Hrelia, S. Polyphenols as modulators of aquaporin family in health and disease. Oxid. Med. Cell. Longev. 2015, 2015, 196914. [CrossRef] [PubMed]

55. Yu, L.; Yi, J.; Ye, G.; Zheng, Y.; Song, Z.; Yang, Y.; Song, Y.; Wang, Z.; Bao, Q. Effects of curcumin on levels of nitric oxide synthase and AQP-4 in a rat model of hypoxia-ischemic brain damage. Brain Res. 2012, 1475, 88-95. [CrossRef] [PubMed]

56. Laird, M.D.; Sukumari-Ramesh, S.; Swift, A.E.; Meiler, S.E.; Vender, J.R.; Dhandapani, K.M. Curcumin attenuates cerebral edema following traumatic brain injury in mice: A possible role for aquaporin-4? J. Neurochem. 2010, 113, 637-648. [CrossRef] [PubMed]

57. Yu, L.S.; Fan, Y.Y.; Ye, G.; Li, J.; Feng, X.P.; Lin, K.; Dong, M.; Wang, Z. Curcumin alleviates brain edema by lowering AQP4 expression levels in a rat model of hypoxia-hypercapnia-induced brain damage. Exp. Ther. Med. 2016, 11, 709-716. [CrossRef] [PubMed]

58. Zu, J.; Wang, Y.; Xu, G.; Zhuang, J.; Gong, H.; Yan, J. Curcumin improves the recovery of motor function and reduces spinal cord edema in a rat acute spinal cord injury model by inhibiting the JAK/STAT signaling pathway. Acta Histochem. 2014, 116, 1331-1336. [CrossRef] [PubMed]

59. Wang, B.F.; Cui, Z.W.; Zhong, Z.H.; Sun, Y.H.; Sun, Q.F.; Yang, G.Y.; Bian, L.G. Curcumin attenuates brain edema in mice with intracerebral hemorrhage through inhibition of AQP4 and AQP9 expression. Acta Pharmacol. Sin. 2015, 36, 939-948. [CrossRef] [PubMed]

60. Nabiuni, M.; Nazari, Z.; Safaeinejad, Z.; Delfan, B.; Miyan, J.A. Curcumin downregulates aquaporin-1 expression in cultured rat choroid plexus cells. J. Med. Food 2013, 16, 504-510. [CrossRef] [PubMed]

61. Ji, C.; Cao, C.; Lu, S.; Kivlin, R.; Amaral, A.; Kouttab, N.; Yang, H.; Chu, W.; Bi, Z.; Di, W.; Wan, Y. Curcumin attenuates EGF-induced AQP3 up-regulation and cell migration in human ovarian cancer cells. Cancer Chemother. Pharmacol. 2008, 62, 857-865. [CrossRef] [PubMed]

62. Laforenza, U.; Gastaldi, G.; Grazioli, M.; Cova, E.; Tritto, S.; Faelli, A.; Calamita, G.; Ventura, U. Expression and immunolocalization of aquaporin-7 in rat gastrointestinal tract. Biol. Cell 2005, 97, 605-613. [CrossRef] [PubMed]

63. Laemmli, U. Cleavage of structural proteins during the assembly of the head of bacteriophage T4. Nature 1970, 227, 680-685. [CrossRef] [PubMed]

64. Laforenza, U.; Scaffino, M.F.; Gastaldi, G. Aquaporin-10 represents an alternative pathway for glycerol efflux from human adipocytes. PLoS ONE 2013, 8, e54474. [CrossRef] [PubMed] 
65. Laforenza, U. Water channel proteins in the gastrointestinal tract. Mol. Aspects Med. 2012, 33, $642-650$. [CrossRef] [PubMed]

66. Laforenza, U.; Cova, E.; Gastaldi, G.; Tritto, S.; Grazioli, M.; LaRusso, N.F.; Splinter, P.L.; D'Adamo, P.; Tosco, M.; Ventura, U. Aquaporin-8 is involved in water transport in isolated superficial colonocytes from rat proximal colon. J. Nutr. 2005, 135, 2329-2336. [PubMed]

67. Bradford, M. A rapid and sensitive method for the quantitation of microgram quantities of protein utilizing the principle of protein-dye binding. Anal. Biochem. 1976, 72, 248-254. [CrossRef]

(C) 2017 by the authors. Licensee MDPI, Basel, Switzerland. This article is an open access article distributed under the terms and conditions of the Creative Commons Attribution (CC BY) license (http:/ / creativecommons.org/licenses/by/4.0/). 